\title{
Performance of Wheat Varieties under Late and Very Late Sowing Conditions
}

\author{
Charanjeet Kaur* \\ PAU Regional Research Station, Gurdaspur, Punjab, India \\ *Corresponding author
}

A B S T R A C T

\begin{tabular}{|l|}
\hline Ke y w o r d s \\
Wheat, varieties, \\
Yield, Late sowing, \\
Very late sowing. \\
\hline Article Info \\
\hline $\begin{array}{l}\text { Accepted: } \\
\text { 10 July 2017 } \\
\text { Available Online: } \\
\text { 10 September } 2017\end{array}$ \\
\hline \hline
\end{tabular}

A field experiment was initiated to study the performance of seven wheat varieties under late and very late sowing conditions. The experiment was laid out in split plot design with fourteen treatment combinations in three replications. Treatments consisted of two sowing conditions i.e. late sown (11.12.2013) and very late sown (06.01.2014) in main plots and seven wheat varieties viz. PBW590, DBW90, WH1129, PBW550, HD3059, WH1021 and WH1124 in the sub plots. The results revealed that there was no statistical difference among sowing dates for yield and yield attributing characters, but significant differences were observed among different varieties in relation to yield and yield contributing parameters like effective tillers $\left(\mathrm{m}^{-2}\right)$, number of grains per spike and 1000 grain weight (g). Among varieties, HD3059 was the top yielder (48.11 $\left.\mathrm{qha}^{-1}\right)$ which proved significantly superior over PBW590, PBW550 and WH1021 and was statistically at par with WH1124, DBW 90 and WH1129. HD3059 can be considered as best variety for growing in late and very late sowing conditions.

\section{Introduction}

Wheat has a prominent position among cereals. It is high source of protein, good source of fibre and good in manganese and magnesium in unrefined state. Its area and productivity is increasing rapidly across the globe, due to its wider adaptability and sustainability under diverse agro climatic conditions (Kumar et al., 2014). There are various factors, which are responsible for low yield of wheat crop in the country but among these sowing time and and varietal selection are of primary importance. Wheat is the main crop of winter season and it has its own definite requirements for temperature and light for emergence, growth and flowering (Dabre et al., 1993).
Selection of suitable crop varieties according to the agroclimatic conditions may play crucial role in realizing the optimum production of any crop commodity (Singh et $a l$. , 2008). Delay in sowing results in poor tillering and crop growth is generally slow due to low temperature. In late planting the wheat variety should be of short duration that may escape from high temperature at the grain filling stage (Phadnawis and Saini, 1992). Late sowing results in reduction of yield contributing characters like number of tillers and number of grains per spike (Ansary et al., 1989). The release of new varieties is a continuous process and different varieties perform differently under different sowing 
conditions. Therefore, the present study was conducted to judge the performance of various wheat varieties under late and very late sowing conditions.

\section{Materials and Methods}

A field experiment was conducted at Regional Research Station, Gurdaspur during the winter (rabi) season of 2013-14. The experimental soil was loam in texture, high in organic carbon, available phosphorus and potash and normal in $\mathrm{pH}$ and electrical conductivity. The 14 treatments were executed in split plot design with three replications. The treatments comprised of two sowing dates in the main plots and seven varieties in the sub plots. The dates of sowing were 11.12.2013 (Late sown condition) and 06.01.2014 (Very late sown condition). The seven varieties viz. PBW 590, DBW 90, WH1129, PBW550 HD 3059, WH1021 and WH1124 were grown in the sub plots. The sowing of the varieties were done by kera method in rows of $18 \mathrm{~cm}$ spacing and at a depth of $4-6 \mathrm{~cm}$. The fertilizers were applied at the rate of $120 \mathrm{Kg} \mathrm{N}, 60 \mathrm{Kg} \mathrm{P}_{2} \mathrm{O}_{5}$ and 40 $\mathrm{Kg} \mathrm{K} \mathrm{K}_{2} \mathrm{O}$ per hectare. $1 / 3^{\text {rd }} \mathrm{N}$, full phosphorus and potash were applied at sowing time and the remaining $2 / 3^{\text {rd }} \mathrm{N}$ were applied as $1 / 3^{\text {rd }} \mathrm{N}$ at first irrigation and $1 / 3^{\text {rd }} \mathrm{N}$ at second irrigation.

All other agronomic practices were kept normal and uniform for all the treatments. The data for germination count per square meter was recorded at 30 days after sowing. The data for other parameters like effective tillers per square meter, number of grains per spike, 1000 grain weight, biological yield and grain yield were recorded at maturity. For collecting data on effective tillers per square meter, three sites of one square meter each were randomly selected from each plot and mean was calculated. Grains per spike were calculated by randomly selecting ten spikes from each plot and then spikes threshed and total number of grain were calculated and then mean value was taken. A random sample of 1000 grains from each treatment was collected and weighed with digital balance for 1000 grain weight. The biological yield and seed yield were recorded on plot basis and were converted to quintal/hactare.

\section{Results and Discussion}

\section{Germination count $\left(\mathrm{m}^{-2}\right)$}

The yield of any crop is determined by its stand count that is function of its initial germination. The germination count was significantly affected by date of sowing. The January sown crop recorded significantly lower germination count $\left(173.3 \mathrm{~m}^{-2}\right)$ as compared to December sown crop (234.7 m 2). This may be due to temperature fluctuation. During the month of January temperature falls and it could not fulfil the requirement for seed germination. Razzaq et al., (1986) also observed the similar findings. The different varieties also showed significant differences in germination count $\left(\mathrm{m}^{-2}\right)$. Maximum germination count was observed in variety WH1021 (218.4 $\mathrm{m}^{-2}$ ) which was at par with WH1124 and PBW550 and significantly more than rest of the varieties. Differences in germination count might be attributed to their genetic diversity. These results are in line with those of Aslam et al., 2003. The interaction between date of sowing and varieties were found to be non-significant.

\section{Effective tillers $\left(\mathrm{m}^{-2}\right)$}

Tillering mainly depends upon the green photosynthetic area which is responsible for carbohydrate formation, grain filling and final grain yield. The wheat crop sown late recorded more tiller production as compared to very late sown crop, however the differences were found to be non-significant, but different varieties showed significant differences in tiller production. 
Table.1 Effect of date of sowing on yield and yield attributes of wheat Varieties

\begin{tabular}{|c|c|c|c|c|c|c|}
\hline Treatments & $\begin{array}{l}\text { Germination } \\
\text { count }\left(\mathbf{m}^{-2}\right)\end{array}$ & $\begin{array}{l}\text { Effective tillers } \\
\left(\mathrm{m}^{-2}\right)\end{array}$ & $\begin{array}{l}\text { Number of Grains } \\
\text { per spike }\end{array}$ & $\begin{array}{l}1000 \text { grain } \\
\text { weight }(g)\end{array}$ & $\begin{array}{l}\text { Biological yield } \\
\text { (q/ha) }\end{array}$ & Yield (q/ha) \\
\hline \multicolumn{7}{|c|}{ Date of sowing } \\
\hline Late & 234.79 & 333 & 35.22 & 36.95 & 99.5 & 43.31 \\
\hline Very late & 173.10 & 325 & 37.18 & 35.89 & 88.1 & 42.96 \\
\hline CD at $5 \%$ & 16.42 & NS & NS & NS & NS & NS \\
\hline \multicolumn{7}{|l|}{ Varieties } \\
\hline PBW 590 & 189.27 & 312 & 36.97 & 36.48 & 83.5 & 41.76 \\
\hline DBW 90 & 200.68 & 350 & 35.30 & 36.68 & 99.6 & 45.19 \\
\hline WH 1129 & 199.52 & 334 & 35.42 & 38.01 & 99.4 & 44.81 \\
\hline PBW 550 & 204.67 & 313 & 36.19 & 36.73 & 82.9 & 41.38 \\
\hline HD 3059 & 199.42 & 321 & 41.66 & 36.63 & 107.7 & 48.11 \\
\hline WH 1021 & 218.47 & 336 & 30.50 & 33.47 & 86.7 & 34.19 \\
\hline WH 1124 & 215.63 & 337 & 37.35 & 36.91 & 96.7 & 46.50 \\
\hline CD at $5 \%$ & 13.20 & 26.07 & 4.15 & 1.63 & 8.0 & 3.78 \\
\hline Interaction & NS & NS & 5.87 & NS & NS & NS \\
\hline
\end{tabular}

Table.2 Interactive effect of date of sowing on grains per spike of wheat varieties

\begin{tabular}{|c|c|c|c|}
\hline \multirow[b]{3}{*}{ Variety } & \multicolumn{3}{|c|}{ Sowing time } \\
\hline & \multirow{2}{*}{\multicolumn{3}{|c|}{ Grains per spike }} \\
\hline & & & \\
\hline PBW 590 & 41.01 & 32.93 & 36.97 \\
\hline DBW 90 & 34.91 & 35.68 & 35.30 \\
\hline WH 1129 & 34.79 & 36.05 & 35.42 \\
\hline PBW 550 & 33.87 & 38.51 & 36.19 \\
\hline HD 3059 & 37.29 & 46.04 & 41.66 \\
\hline WH 1021 & 27.44 & 33.56 & 30.50 \\
\hline WH 1124 & 37.25 & 37.46 & 37.35 \\
\hline Mean & 35.22 & 37.18 & 36.20 \\
\hline CD at $5 \%$ & & & \\
\hline Date of sowing & NS & & \\
\hline Varieties & 4.15 & & \\
\hline Interaction & 5.87 & & \\
\hline
\end{tabular}


Among the varieties, DBW90 produced maximum number of tillers which were at par with varieties WH1124, WH1021, WH1129 and HD3059 and significantly superior than PBW550 and PBW590. The differential variation for tiller production among genotypes might be due to their genetic variability (Aslam et al., 2003; Khaliq, 2004 and Shah et al., 2006) The interactive effects between date of sowing and varieties were non-significant.

\section{Number of grains spike $\mathrm{e}^{-1}$}

Number of grains per spike is an important yield attributing character. Data regarding number of grains per spike revealed that sowing dates did not affect significantly the number of grains per spike but significant differences were observed among varieties. The interaction between sowing dates and varieties was found to be significant. The variety HD3059 produced highest grains (41.66) per spike and it remained significantly superior over all other varieties. Variety WH1021 recorded the lowest number of grains per spike in late sowing conditions. Differences in number of grains spike ${ }^{-1}$ among varieties might be due to their genetic variability. Similar results were reported by Haider (2004).

\section{0 grain weight $(g)$}

The data regarding 1000 grain weight revealed that sowing conditions and different varieties and even interaction of both did not significantly affect the 1000 grain weight. However, the crop sown under very late sowing conditions recorded lower 1000 grain weight as compared to crop sown under late sown conditions. Many workers reported decrease in grain weight due to late sowing (Khan, 2000; Akhtar et al., 2006). This is because, delay in sowing shortens the duration of each development phase which ultimately reduces the grain filling period leading to lower grain weight (Spink et al., 2000). Among varieties, maximum 1000 grain weight was observed in WH1129 (38.01g) whereas least (33.47 g) was observed in variety WH1021.

\section{Biological yield $\left(\mathrm{qha}^{-1}\right)$}

Biological yield is reflected by growth parameters like leaf area, tiller production and plant height. It is evident from data that biological yield was not significantly affected by date of sowing, but different varieties showed significant effect on biological yield. The variety HD3059 recorded highest biological yield whereas least was observed in variety PBW550. The interaction between date of sowing and variety was found to be non-significant.

\section{Grain yield (qha $\left.{ }^{-1}\right)$}

Grain yield of wheat crop is the combined effect of various yield attributing components. As shown in table 1 that different sowing conditions did not affect grain yield, but significant differences were found among different varieties in relation to grain yield. Among varieties, HD3059 recorded maximum yield $(48.11 \mathrm{q} / \mathrm{ha})$ and it was statistically at par with WH1124, DBW 90 and WH1129 and significantly superior over PBW590, PBW550 and WH1021.The variety WH1021 recorded significantly lower yield as compared to all other varieties and it was 28.9 percent lower yield than HD 3059. The highest yield of variety HD3059 might be due to maximum number of grain per spike. No interaction effects were observed between sowing dates and different genotypes (Table 2).

It can be summarised that variety HD3059 can be considered as best among seven genotypes for growing under late and very 
late sowing conditions.

\section{Acknowledgement}

The author want to express sincere gratitude to Directorate of Wheat Research, Karnal for providing facilities under "All India coordinated research project on Wheat and Barley" for the conduct of this research.

\section{References}

Akhtar, M., M.S. Cheema, M. Jamil and Ali, L. 2006. Effect of time of sowing on some important characters of wheat, Triticum aestivum, genotypes. J. Agric. Res. 44(4): 255-259.

Ansary, A.H., A.M. Khushak, M.A. Sethar, N.A. Ariam and Emon, M.Y.M. 1989. Effect of sowing dates on growth and yield of heat cultivars. Pak. J. Sci. Ind. Res. 32: 39-42.

Aslam, M., M. Hussain, M. Akhtar, M.S. Cheema and Ali, L.2003. Response of wheat varieties to sowing dates. Pak. J. Agron. 2(4):190-194.

Dabre, W.M., S.B. Lall and Lngole, G.L. 1993. Effects of sowing dates on yield, ear number, stomatal frequency and stomatal index in wheat. J. Maharashatra Agric. Univ.18: 64-66.

Haider, R.S., 2004. Growth and yield response of three wheat varieties to $\mathrm{N}$ alone and in combination with $\mathrm{P}$ and $\mathrm{P}+\mathrm{K}$ under late sown conditions. M.Sc. (Hons.) Agri. Thesis, University of Agricuture, Faisalabad-Pakistan.

Khaliq, D., 2004. Modeling the growth, radiation use efficiency and yield of wheat under different sowing dates and varying nitrogen levels under rainfed conditions. M.Sc. (Hons.)Thesis, University of Agriculture, FaisalabadPakistan.

Khan, N.A., 2000. Simulation of wheat growth and yield under variable sowing date and seeding rate. M.Sc. Thesis, Department of Agronomy, University Agriculture, Faisalabad.

Kumar, P., A. Sarangi, D. K. Singh and Parihar, S.S.2014. Wheat performance as influenced by saline irrigation regimes and cultivars. Journal of Agri Search1 (2): 66-72.

Phadnawis, B.N., and Saini, A. D.1992.Yield models in wheat based on sowing time and phenological developments. Ann. Pl. Physio, 6: 52-59.

Razzaq, A., P. Shah, B. Sartaj Khan, K. Saeed and Mohammad, D.1986. Effect of planting times on the growth and straw yield of wheat varieties. Sarhad J. Agric., 2(2): 327-334.

Shah, W.A., J. Bakht, T. Ullah, A.W. Khan, M. Zubair and Khakwani. A. 2006. Effect of sowing dates on yield and yield components of different wheat varieties. J. Agron. 5(1):106-110.

Singh, A.K., N. Manibhushan, Chandra and Bharati, R.C.2008. Suitable crop varieties for limited irrigated conditions in different agro climatic zones of India. Int. J. Trop Agr. 26 (3-4): 491-496.

Spink, J.H., E.J.M. Kirby, D.L. Forest, R. Sylvester Bradley, R.K. Scott, M.J. Fouke's, R.W. Clare and Evans, E.J.2000. Agronomic implications of variation in wheat development due to variety, sowing, site and season. Plant, Variety and Seed 13: 91-105

\section{How to cite this article:}

Charanjeet Kaur. 2017. Performance of Wheat Varieties under Late and Very Late Sowing Conditions. Int.J.Curr.Microbiol.App.Sci. 6(9): 3488-3492. doi: https://doi.org/10.20546/ijcmas.2017.609.428 